\title{
Transmission of Urinary Schistosomiasis among School Aged Children in Owena, Kajola and Baiken Communities Bordering Owena Reservoir/Dam, Ondo East Local Area, Ondo State, Southwest, Nigeria
}

\section{Peletu BJ1*, Ofoezie IE ${ }^{2}$ and Olaniyan $\mathrm{RF}^{3}$}

${ }^{1}$ Department of Biological Sciences, College of Natural and Applied Sciences (CNAS), Wesley University Ondo, Ondo State, Nigeria ${ }^{2}$ Institute of Ecology and Environmental Studies, Obafemi Awolowo University, Ile-Ife, Nigeria

${ }^{3}$ Department of Biology, Adeyemi College of Education, Ondo, Nigeria

\begin{abstract}
Background: Schistosomiasis is a snail-borne, water-based parasitic infection caused by blood-dwelling (hence called blood-fluke) trematode worms of the genus Schistosoma. It is a disease of the poor and marginalized. Schistosomiasis remains an important public health problem globally with approximately 779 million estimated to be at risk. This study was carried out to ascertain the prevalence of the disease among school children in the three communities: Owena, Kajola and Baiken with a view to providing important parasitological information and boosting can sustainable control strategies of the disease.
\end{abstract}

Methods: A school based cross-sectional technique was used to collect data on risk factors from 624 school children in March 2014 and 591 in April 2015. Urine samples were collected between the hours of 10:00 am 12:00 pm GMT in dry labeled wide mouthed. Plastic urine container $(300-500 \mathrm{ml})$ each $10 \mathrm{ml}$ was centrifuged and examined for the presence or absence of more nutobiuk eggs. Using X40 objectives of a light microscope. Infection intensity was recorded as number of eggs per $10 \mathrm{ml}$ of urine sample. The intensity of infection was graded as heavy 500 eggs/10 $\mathrm{ml}$ urine, moderate $(51-499$ eggs/10 $\mathrm{ml}$ urine) or light (50 eggs/10 ml urine). Data obtained were analyzed using version 20.0 of the Statistical Package for The Social Sciences (SPSS) for windows Software Packages (SPSS on Chicag oil, 2013).

Results: Our of the 624 pupils examined in 2014, 256 (41.0\%) were positive for S. haematobium eggs in urine, while in 2015, $381(64.5 \%)$ out of 591 were positive. Thus, there was a $23 \%$ increase in prevalence between the two genera. Individual intensity of infection varied from 1-6, 468 eggs/10 ml urine. Meaning the most heavily infected pupil in 2015 exceeded more than 68\% infection in 2014. The arithmetic memory 2016 in moles was 0.65 in 2015 it was 0.09 , while that of females in 2014 was 0.05 and 0.08 in 2015 .

Conclusion: This study area in Owena, Kajola and Baiken communities bordering Owena Reservoir/Dam, Ondo East Local Government Area, Ondo State, Nigeria show risk communities for urinary schistosomiasis. The overall pattern of $S$. haematobium eggs per $10 \mathrm{ml}$ urine in the three communities in the two years (March 2014 and April 2015) study shows that it was sex and age dependent. The age-group with highest prevalence is $11-15$ years in 2014 and $55.4 \%$ in 2015 with range infection for males was $43.6 \%$ in 2014 and 71.86 in 2015, while that of females was $37.0 \%$ in 2014 and $57.0 \%$ in 2015 . Therefore, it is recommended that all school-age children especially those in 11-15 age-group should be treated using chemotherapy method. Pipe-borne water to prevent people having contact with the infected fresh water, sewage disposal facilities provided, mass educational therapy (societal sensitization/ health education) is required to reduce infection and transmission of urinary schistosomiasis.

Keywords: Schistosoma haematobium urinary; Microhaematuria; Schistosomiasis; School-aged pupil; Ondo State; Nigeria

\section{Introduction}

Out of the five schistosomes species infecting humans, Schistosoma mansoni and Schistosoma haematobium are of great medical importance [1-4]. Schistosoma haematobium is found in the venous plexus draining the urinary bladder of human [5,6]. Infection results from the parasite depositing terminal spined eggs which clog the venous plexus, preventing blood flow, which leads to the bursting of the veins, allowing blood and eggs to enter the urinary bladder, resulting to the characteristic symptom of blood in urine, haematuria [6-8].

Chronic pathology and morbidity of urinary shcistosomiasis are caused by eggs trapped in tissues during the pervesical migration or after embolisation (blockage) in the livers spleen, lungs or cerebrospinal system $[9,10]$. Once in the tissues, the eggs secrete proteolytic enzymes that provoke granulomatons inflammation, ulceration, pseudopolyposis of the vesical and ureteral walls $[8,11]$.
Schistosomiasis is a snail-borne, water-based parasitic infection caused by blood-dwelling (hence called blood-fluke) trematode worms of the genus Schistosoma [12]. The infection is now commonly known as bilharziasis; swimmer's itch, snail fever, katayama fever, blood fluke, Tsargiyya in Hausa, Atosiaja in Yoruba languages in Nigeria $[4,8,13$ $16]$.

*Corresponding author: Peletu BJ, Department of Biological Sciences, College of Natural and Applied Sciences (CNAS), Wesley University Ondo, Ondo State, Nigeria, Tel: +2348033605295; E-mail: peletubayo@gmail.com

Received September 19, 2017; Accepted October 31, 2017; Published January 02, 2018

Citation: Peletu BJ, Ofoezie IE, Olaniyan RF (2018) Transmission of Urinary Schistosomiasis among School Aged Children in Owena, Kajola and Baiken Communities Bordering Owena Reservoir/Dam, Ondo East Local Area, Ondo State, Southwest, Nigeria. Hydrol Current Res 9: 289. doi: 10.4172/2157-7587.1000289

Copyright: @ 2018 Peletu BJ, et al. This is an open-access article distributed under the terms of the Creative Commons Attribution License, which permits unrestricted use, distribution, and reproduction in any medium, provided the original author and source are credited. 
Citation: Peletu BJ, Ofoezie IE, Olaniyan RF (2018) Transmission of Urinary Schistosomiasis among School Aged Children in Owena, Kajola and Baiken Communities Bordering Owena Reservoir/Dam, Ondo East Local Area, Ondo State, Southwest, Nigeria. Hydrol Current Res 9: 289. doi: $10.4172 / 2157-7587.1000289$

Page 2 of 8

Schistosomiasis, filariasis, leprosy, leishmaniasis, malaria and trypanosomiasis are the six major tropical diseases, specially targeted for control by the Special Programme for Research and Training on Tropical Diseases of the United Nations Development Programme (UNDP), The World Bank and The World Health Organization. $[1,3,10,14,15,17,18]$. Schistosomiasis is the second important tropical disease inferior to malaria [8].

The distribution of schistosomiasis cuts across 76 countries in African, Latin Ameria and Asia. Schistosoma haematobium endemicity cuts across 54 countries in Eastern Mediteranean. S. mansoniis endemic in 53 countries of Caribean, South America, the Eastern Mediteranean and Africa. S. intercalatumis reportedly endemic in 10 Central African nations $[1,3,10]$.

Ofoezie [13] reported that the disease is endemic in 23 of the 36 states in Nigeria while its status in 13 other states is unknown (i.e., no record does not mean no case). Recent studies have shown that the disease also occurs in some of these states with unknown status e.g., Ondo $[3,15,19]$.

In sub-Saharan Africa there is evidence of a link between the occurrence of human schistosomiasis and several human factors such as religion, primary occupation, educational level, household income, sanitary facilities, principal source of water supply, age variation, distance of river from residence, and the proportion of individuals less than 15 years old in households [20-22]. By consensus, however, the most important driving factor is availability of appropriate water habitats for snail breeding with human water contact patterns, which on its own is driven by poverty and ignorance.

Although, Ondo State has now joined the unenviable list of states where schistosomiasis occurs, epidemiological information of the disease in the state is still very scanty. Ondo State is drained by Owena River and while prevalence of infection has been reported from various communities along some tributaries of the river, there is no information on detailed transmission studies along Owena River itself $[3,15,19]$. The damming of Owena River since 1966 underscores the importance of elucidating its contribution to schistosomiasis transmission in the State. For instance, studies by Ogbeide et al. [23] show that the reservoir and its tributaries provide water to over $95 \%$ of residents in Ondo, Akure and Ado-Ekiti, as well as, several other smaller settlements along their courses. In spite of this, there is no detailed information on schistosomiasis transmission along the river basin. It cannot be over emphasized that no sustainable schisitosomiasis control can be achieved for Ondo State until a clear picture of the status and contribution of Owena River and Owena Reservoir to overall transmission in the state is elucidated. This is the hallmark of this investigation.

No up-to-date thorough work in Nigeria has been done on the transmission of urinary schistosomiasis among school aged children in Owena, Kajola and Baiken Communities bordering Owena Reservoir, Ondo East Local Government Area. The main objective of the study is to determine the prevalence and the intensity of urinary shcistosomiasis in terms of eggs count $/ 10 \mathrm{~m} / \mathrm{g}$ urine as regards the source of water supply in the three selected communities around Owena Reservoir (Dam) school aged children.

\section{Materials and Methods}

\section{Study area}

The cross-sectional study was carried out in Owena Reservoir and its adjoining three randomly selected communities (Owena, Kajola and Baiken) which are rural to semi-urban settlement in Ondo East Local Government Area, Ondo State (Figure 1) and lies between $7^{\circ} 00^{\prime}-7^{\circ} 30^{1}$ $\mathrm{N}$ and longitudes $5^{\circ} 00^{1}-5^{\circ} 30^{1}$ E. Further illustrations are presented in the map of Owena showing OwenaDam and the eight sampling sites of Owena, Kajola and Baiken Communities (Figure 2) and the map of Owena showing Owena Reservoir and the eight sampled sites.

\section{Urine collection and quantification of Schistosoma haematobium eggs}

A school-based cross-sectional technique was used for urine collection and quantification of Schistosoma haematobium eggs $[8,24]$ This is on the basis that children, especially school aged-children represent the prime reservoir for the schistosome parasites and children are more amenable to mass chemotherapy than adults $[10,25]$. From the three randomly selected riparian communities, (Owena-Ondo, Kajola and Baiken) three schools (one from each of the communities) were selected on the basis of their proximity to the water bodies [26]. These schools include Owena Communitiy Grammar School, Owena, Ebenezer (Anglican Primary School, Kajola) and St. Peter's (RCM) Primary School, Baiken. Urine collection and examination for Schistosoma haematobium eggs were carried out in March 2014 and April 2015.

\section{Data collection}

In 2014, urine samples were collected from a total of 624 school aged-children in the three communities combined. In 2015, urine samples were collected from the same above-named schools to the total of 591. The collection and examination of urine samples were carried out using the sedimentation by gravity cum centrifugation technique as described by Asaolu et al. [27-30]. Each pupil was given a clean dry labeled wide mouthed plastic urine container $(300-500 \mathrm{ml})$ to provide a urine sample between the hours of 10 am and 12 pm GMT, the best time interval of eggs deposit in the bladder [10,31]. The urine sample provided was thoroughly mixed before two $10 \mathrm{ml}$ sub-samples were transferred into two separate $30 \mathrm{ml}$ universal sterlin plastic bottles with conical bottom $[26,27,32]$. Immediately after dividing into two sub-sample, the first of the two subsamples was preserved with a view to preventing the eggs from hatching $[8,29]$ while the second content was assessed for gross (visible) haematuria and micro-haematuria. The first content was preserved with $5 \mathrm{ml}$ of $10 \%$ formalin, covered tightly, properly labeled and taken to the parasitology laboratory at the University of Ibadan, Department of Zoology for examination for the presence of Schistosoma haematobium eggs.

\section{Laboratory analysis}

In the laboratory the preserved urine samples were properly shaken, held in and upward position for at least four hours to allow schistosome eggs settles by gravity in the groove of the conical bottom [27]. The clear supernatant was carefully withdrawn with a needle attached syringe. The remaining content (the sediment) was thoroughly mixed. From each sample, $10 \mathrm{ml}$ of the urine (sediment) was transferred to a centrifuge tube and spun at 5000 revolutions per minute for five minutes in a centrifuge [30]. The supernatant was discarded, and the sediment transferred into a clean grease-free slide, covered with a cover slip and examined microscopically using X40 objective of a light microscope to identity Schistosoma haematobium eggs, which is characterized by the presence of a terminal spine. The intensity of infection was graded according to $[16,29,30,33]$ as heavy ( $\geq 500$ eggs $/ 10 \mathrm{~m} /$ urine) moderate (51-499 eggs/10 m/urine) or light ( $\geq 50$ eggs $/ 10 \mathrm{ml} /$ urine). Each of the 
Citation: Peletu BJ, Ofoezie IE, Olaniyan RF (2018) Transmission of Urinary Schistosomiasis among School Aged Children in Owena, Kajola and Baiken Communities Bordering Owena Reservoir/Dam, Ondo East Local Area, Ondo State, Southwest, Nigeria. Hydrol Current Res 9: 289. doi: 10.4172/2157-7587.1000289

Page 3 of 8

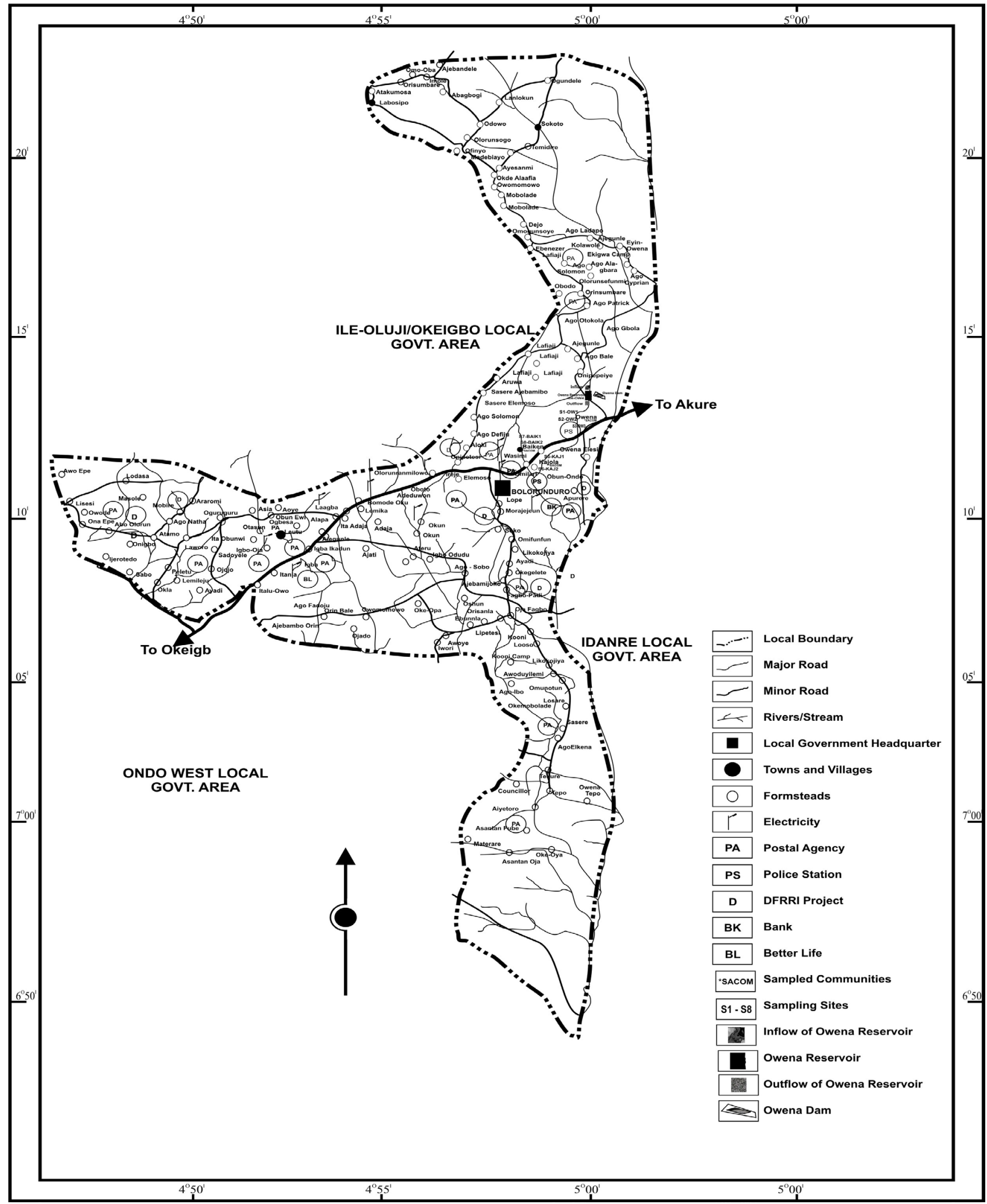

Figure 1: Map of Ondo East Local Government Area, Ondo State, Nigeria, showing Owena Reservoir Area, the three sampled communities (Owena, Baiken, and Kajola), Owena Dam, Owena River and the eight sampling sites. Source: Igboloro and Associates (Planners, Architects and Engineers), 3, Ayodele Awodeyi Street, Ketu, Lagos, Lagos State, Nigeria (2012). 
Citation: Peletu BJ, Ofoezie IE, Olaniyan RF (2018) Transmission of Urinary Schistosomiasis among School Aged Children in Owena, Kajola and Baiken Communities Bordering Owena Reservoir/Dam, Ondo East Local Area, Ondo State, Southwest, Nigeria. Hydrol Current Res 9: 289. doi: $10.4172 / 2157-7587.1000289$

Page 4 of 8

samples was recorded as $S$. haematobium eggs per sediment volume expressed as number of eggs per $10 \mathrm{ml}$ urine [27,34]. Using the second content of the two sub-samples, microhaematuria was assessed. Microhaematuria was determined using one strip of commercially prepared chemical reagent strips Combur-9, marketed and prepared by Acon Laboratory, USA, dipped into each urine sample and the colour change was matched with standard colours by the side of the container of the reagent strips. Results indicated positive haematuria, which changed the colour of the strip from yellow to light green (light haematuria), deep green (moderate haematuria) or deeper (Heavy green (heavy haematuria) while negative haematuria indicated no colour change of the reagent strip. However, all the positive/negative haematuria results were recorded as either green colour change or no colour change respectively. Other variables such as sex, weight, height, religion, tribe of each pupil was determined. Height was measured with a calibrated pole, with individuals standing barefoot on the flat cemented floors of their classrooms. Body weight was determined using a standard bathroom scale. Religion, tribe and other variable were determined by oral interview of each of the pupils.

\section{Administration of structured questionnaire}

Relevant data were collected using interview based on pretested well-structured questionnaire in the language preferred by the interviewee, commonly English, Yoruba, Igbo, Hausa and others. From March 2014 to April 2015, 765 questionnaires were administered to school aged-children, some of their teachers and other adult members of the three communities. Out of 765 questionnaires distributed, only $632(82.6 \%)$ were recovered. Out of the 632 questionnaires recovered, $580(91.8 \%)$ was from school aged-children children and $52(8.2 \%)$ from adults in the communities. The questionnaire was used to collect demographic and socio-economic data, with a view to exploring the schistosomiasis-related knowledge perception, attitude, understanding of transmission of each participant [16]. Other variables collected included personal biodata (sex, name, age, marital status, tribe, religion educational background, occupation) period of residency in the communities, source of water supply, access to sanitation facilities (latrine type, water closet, dunghill, open space of defecation). Details of the questions in the questionnaire are presented.

\section{Statistical analysis}

The egg counts, the 2-score data of distribution pattern was determined by the kolmogorov-smirnov goodness of fit less for normality, the normal probability plots and/or the Shapiro-Wilk test for normality [35]. Various transformations, since none of these variables were normally distributed, were tested resulting into a logarithmic transformation of eggs positive only. Egg counts. Consequently, data were analysed by parametric tests and the rest by the non-parametric test. Parasitological (Human Infection).

Prevalence of $S$. haemtobium contingency test were used to compare prevalence and reinfection between the three communities, sex, agegroups, occupation, tribe, religion. The multivariate logistic regression analysis was used to determine the relative predictive strength after adjusting for the effect of other variables, since many of these factors were inter-related. The result presented as off ratio which implies the increase in odds of an event when the value of an independent variable increases by one [36].

\section{Intensity of infection}

Intensity infection of all analyses were performed only on the log transformed positive egg counts with only geometric mean egg counts presented in the tables. Differences dichotomous (e.g., sex) variable were determined by the student $\mathrm{t}$-test, between more than two-level discrete (e.g., occupation) or categorized continuous (e.g., age groups, variable by one-way analysis of variance. Relationship between egg counts and continuous independent variables (e.g., age) were determined by the Pearson's product moment correlation coefficient [37].

\section{Infection pattern by age and sex}

There is significant different $\left(\mathrm{x}^{2}=4.04, \mathrm{df}=3 \mathrm{p}<0.04\right)$. There is significant different in the age group $\left(\mathrm{x}^{2}=0.17, \mathrm{df}=1 \mathrm{p}<0.02\right)$ between males and females.

The overall pattern of S. haematobium prevalence in March 2014 and April 2015 are presented in Table 1. Prevalence of infection was highest $(55.5 \%)$ in the age group 11-15 years in 2014 and least $(27 \%)$ in the age group 5-10 years old. In 2015, the highest prevalence of $73.09 \%$ also occurred among the age bracket 11-15 years old while the least (53.6\%) was recorded among the 5-10 years old bracket. Thus, while peak prevalence increased by $17.6 \%$, the least increased by 26.6 . As regard sex as a variable, the intensity is sex dependent. In 2014, the prevalence rate of makes was $43.6 \%$ in 2014 and $71.9 \%$ in 2015 , for females, the prevalence rate was 39.0\% in 2014 and 57.1\% in 2015.

\section{Results}

\section{Prevalence and intensity of infection in urine sample}

Table 1 summarizes the prevalence and mean intensity $\left(\log _{10}\right.$ egg counts per $10 \mathrm{ml}$ urine), of infection in different population groups examined. Out of 624 pupils examined in 2014, 256 (41.0\%) were positive for S. haematobium eggs in urine, while in 2015, 381 (64.5\%) out of 591 were positive. Thus, there was a $23 \%$ increase in prevalence between the two years. Individual intensity of infection varied from 1-6,468 eggs/ $10 \mathrm{ml}$ urine meaning the most heavily infected pupil in 2015 exceeded more than $68 \%$ infection in 2014 . The arithmetic means of 2014 in male was 0.65 , in 2015 it was 10.09 , while that of females in 2014 was 0.5 and 0.8 in 2015.

Table 2 illustrates the infection pattern by communities. In Owena, the prevalence increased from $40.7 \%$ in 2014 to $66.8 \%$ in 2015 . In Kajola communities in 2014 the rate was $37.8 \%$, in 2015, 69.67\%. In Baiken communities, the rate was $45.8 \%$ in 2014, and $65.8 \%$ in 2015 . The average rate for each community was $53.8 \%$ at Owena, $48.9 \%$ at Kajola, and $55.8 \%$ at Baiken, indicating that Baiken is the most $(55.85 \%)$ infected community is the two- year study. This is because Baiken community is at the extreme end from the main road the remotest part of the three communities, lacking pipe born-water system, depending only on natural fresh water bodies, the reservoir, Owena River courses, as well the lowest treatment facilities after being infected with urine schistosomiasis. The overall distribution of infection in the three combined communities is significantly difference $(\mathrm{p}<0.001)$.

\section{Prevalence and intensity of haematuria in Owena, Kajola and Baiken (March 2014 and April 2015)}

In Owena, for the two-year (March 2014-April 2015) studies the age group that had the high rate of blood in urine (haematuria) was 21-30 years with $49.2 \%$, the least $21-30$ years with $37.8 \%$. At Kajola community, age group with the highest rate was 5-10 year with $46.2 \%$, the least $11-15$ years with $4.0 \%, 16-20$ years and $21-30$ years had no blood in urine. At Baiken community, the age group with the highest prevalence was $11-15$ years with $56.2 \%$ the least 5-10 years with prevalence of $55.5 \%$. From the above, the community with overall 
Citation: Peletu BJ, Ofoezie IE, Olaniyan RF (2018) Transmission of Urinary Schistosomiasis among School Aged Children in Owena, Kajola and Baiken Communities Bordering Owena Reservoir/Dam, Ondo East Local Area, Ondo State, Southwest, Nigeria. Hydrol Current Res 9: 289. doi: 10.4172/2157-7587.1000289

Page 5 of 8

\begin{tabular}{|c|c|c|c|c|c|c|c|c|c|c|c|}
\hline \multirow{3}{*}{ Variable } & \multirow{3}{*}{ Cases } & \multicolumn{2}{|c|}{ Number Examined } & \multicolumn{2}{|c|}{ Number Positive } & \multicolumn{2}{|c|}{ Prevalence (\%) } & \multicolumn{4}{|c|}{ Mean Log10 (eggs/10 ml urine) } \\
\hline & & \multirow{2}{*}{2014} & \multirow{2}{*}{2015} & \multirow{2}{*}{2014} & \multirow{2}{*}{2015} & \multirow{2}{*}{2014} & \multirow{2}{*}{2015} & \multicolumn{2}{|c|}{2014} & \multicolumn{2}{|c|}{2015} \\
\hline & & & & & & & & Mean & \pm St. D & Mean & \pm St. D \\
\hline \multirow{2}{*}{ Sex } & Male & 273 & 295 & 119 & 212 & 43.59 & 71.86 & 145.2 & 116.93 & 192.95 & 112.78 \\
\hline & Female & 351 & 296 & 137 & 169 & 39.03 & 57.09 & 175.68 & 159.54 & 174.03 & 119.53 \\
\hline Total & & 624 & 591 & 256 & 381 & 41.01 & 64.46 & 160.44 & 126.21 & 183.49 & 104.45 \\
\hline$x^{2}$ & & & & & & & 0.17 & & & & \\
\hline$D f$ & & & & & & & 1 & & & & \\
\hline P-value & & & & & & & 0.02 & & & & \\
\hline \multirow{4}{*}{$\begin{array}{c}\text { Age Group } \\
\text { (Years) }\end{array}$} & 5 to 10 & 263 & 231 & 71 & 123 & 27 & 53.25 & 120.33 & 125.5 & 135.75 & 89.56 \\
\hline & 11 to 15 & 283 & 275 & 157 & 201 & 55.48 & 73.09 & 165.16 & 113.98 & 183.03 & 102.15 \\
\hline & 16 to 20 & 57 & 41 & 22 & 28 & 38.6 & 68.29 & 39.2 & 17.51 & 45.76 & 20.56 \\
\hline & 21 to 30 & 21 & 44 & 6 & 29 & 28.57 & 65.91 & 18.52 & 11.49 & 46.3 & 18.56 \\
\hline$x^{2}$ & & & & & & & 4.04 & & & & \\
\hline$D f$ & & & & & & & 3 & & & & \\
\hline P-value & & & & & & & 0.04 & & & & \\
\hline \multirow[t]{4}{*}{ Tribe } & Yoruba & 534 & 500 & 215 & 319 & 40.26 & 63.8 & 263.09 & 250.36 & 294.27 & 219.15 \\
\hline & Hausa & 5 & 7 & 2 & 5 & 40 & 71.43 & 15.67 & 21.13 & 27.81 & 37.79 \\
\hline & Igbo & 68 & 65 & 31 & 44 & 45.59 & 67.69 & 48.2 & 18.64 & 58.9 & 12.97 \\
\hline & Others & 17 & 19 & 8 & 13 & 47.06 & 68.42 & 24.02 & 20.45 & 33.47 & 30.41 \\
\hline$x^{2}$ & & & & & & & 0.69 & & & & \\
\hline$D f$ & & & & & & & 3 & & & & \\
\hline P-value & & & & & & & 0 & & & & \\
\hline \multirow[t]{3}{*}{ Religion } & Christianity & 468 & 450 & 186 & 284 & 39.74 & 63.11 & 231.25 & 217.69 & 265.7 & 194.09 \\
\hline & Islam & 95 & 86 & 38 & 59 & 40 & 68.6 & 57.67 & 32.35 & 71.2 & 13.69 \\
\hline & Others & 61 & 55 & 32 & 38 & 52.46 & 69.09 & 48.49 & 14.9 & 54.03 & 15.57 \\
\hline$x^{2}$ & & & & & & & 0.99 & & & & \\
\hline$D f$ & & & & & & & 2 & & & & \\
\hline P-value & & & & & & & 0.02 & & & & \\
\hline
\end{tabular}

Table 1: Prevalence and mean intensity log10 (egg count per $10 \mathrm{ml} /$ urine) of Schistosoma haematobium infection in different population sub-groups in Owena, Kajola and Baiken Communities (March 2014 and April 2015).

haematuria prevalence was $43.5 \%$ was Owena Community the least $45.4 \%$. What would have been accounted for was that Owena school age children are prone to poor treatment and relatively depended for their means of water supply (Table 3 ).

Table 4 summarizes the community perception of schistosomiasis. A total of 632 school aged individuals were interviewed in respect of their knowledge, attitude, perception and understanding of the symptoms, etiology and mode of transmission of schistosomiasis. Out of these, 592 (93.4\%) responded haematuria (blood in urine) was well recognized in the three communities as a sign of urinary schistosomiasis. Danger of blood in urine has no significant difference $(\mathrm{p}<0.05)$ in the community. Their perception of the risk factors associated with schistosomiasis infection was discovered to vary according to the educational background, tribe, and occupation of respondents. Generally, the more educated people are, tribally the Yorubas, and the civil servants were more likely to see schistosomiasis as a serious health problem than other groups.

About $88.8 \%$ of respondents had seen snails around the reservoir, but most were ignorant $(88.9 \%)$ of the fact that snails were involved in the transmission of urinary schistosomiasis. These variations were significantly different $(\mathrm{p}<0.05)$. As regards water supply (source of water), most $(53.3 \%)$ of the residents of the communities made use of river, while the least (2.4\%) used pond. Most (91.6\%) of the residents used river as sanitary facility. As regards treatment of the disease, most of the residents $(62.0 \%)$ used self-medication as method.

\section{Discussion}

The overall pattern of Schistosoma haematobium eggs per $10 \mathrm{~m} /$ urine in the three communities in the two-year (March 2014 and April in 1015) study shows that it was sex and age dependent. In this study, the age-group with the highest prevalence was 11-15 years in 2014 and $55.38 \%$ in 2015 , with range infection of $26.25 \%$. The infection was also sex dependent. The prevalence of infection for males was $43.59 \%$ in 2014 and $71.86 \%$ in 2015 , and while that of females was $37.03 \%$ in 2014 and $57.0 \%$ in 2015. This is because more males took part in more complete water contact activities such as swimming, bathing with higher duration of contact, than the females in the communities. Those in 11-15 years old age group got themselves involved in swimming, bathing than other groups. Most of the females were not always allowed to swim in the river, with the ignorant belief that the only source of water supply in the communities could be contaminated if women under menstruation wash of bath in the water body. The importance of community on the access to modern water supply. Baiken is at the remotest part of the communities, from the Owena community with few Pipe-borne water. 55.65\% of Baiken residents source of water supply is rivers, stream, indicating that they have the highest exposure of water contact than other communities. It may be suggested that, though the two communities Owena and Kajola may be treated, of the disease schistosomiasis, Baiken residents should be mostly treated.

\section{Conclusion}

The study concluded that schistosomiasis transmission which was active in the reservoir is a public health concern to the exposed populations was caused by ignorance, poor sanitary facilities, and water supply with intensive water contact patterns. 
Citation: Peletu BJ, Ofoezie IE, Olaniyan RF (2018) Transmission of Urinary Schistosomiasis among School Aged Children in Owena, Kajola and Baiken Communities Bordering Owena Reservoir/Dam, Ondo East Local Area, Ondo State, Southwest, Nigeria. Hydrol Current Res 9: 289. doi: 10.4172/2157-7587.1000289

Page 6 of 8

\begin{tabular}{|c|c|c|c|c|c|c|c|c|c|c|}
\hline \multirow{3}{*}{ Community } & \multicolumn{2}{|c|}{ Number Examined } & \multicolumn{2}{|c|}{ Number Positive } & \multicolumn{2}{|c|}{ Prevalence (\%) } & \multicolumn{4}{|c|}{ Mean Log10 (eggs/10 ml urine) } \\
\hline & \multirow{2}{*}{2014} & \multirow{2}{*}{2015} & \multirow{2}{*}{2014} & \multirow{2}{*}{2015} & \multirow{2}{*}{2014} & \multirow{2}{*}{2015} & \multicolumn{2}{|c|}{2014} & \multicolumn{2}{|c|}{2015} \\
\hline & & & & & & & Mean & \pm St.D & Mean & \pm St.D \\
\hline Owena & 241 & 229 & 98 & 153 & 40.7 & 66.8 & 0.6 & \pm 0.76 & 0.9 & \pm 0.71 \\
\hline Kajola & 217 & 207 & 82 & 126 & 37.8 & 60.9 & 0.51 & \pm 0.69 & 0.83 & \pm 0.71 \\
\hline Baiken & 166 & 155 & 76 & 102 & 45.8 & 65.8 & 0.7 & \pm 0.78 & 0.95 & \pm 0.75 \\
\hline$x^{2}$ & & & & & & 0.272 & & & & \\
\hline$D f$ & & & & & & 1 & & & & \\
\hline Sig. & & & & & & 0.001 & & & & \\
\hline
\end{tabular}

Table 2: The prevalence of Owena, Kajola and Baiken communities (between March 2014 and April 2015). Source: Peletu- Field Survey of Owena Reservoir Area, Owena, Kajola and Baiken communities (between March 2014 and April 2015).

\begin{tabular}{|c|c|c|c|c|}
\hline Age group (years) & Total Examined & Number Negative & Number Positive & Prevalence (\%) \\
\hline \multicolumn{5}{|c|}{ Owena } \\
\hline 5 to 10 & 13 & 8 & 5 & 38.46 \\
\hline 11 to 15 & 294 & 177 & 117 & 39.8 \\
\hline 16 to 20 & 98 & 61 & 37 & 37.76 \\
\hline 21 to 30 & 65 & 33 & 32 & 49.23 \\
\hline \multicolumn{5}{|l|}{ Kajola } \\
\hline 5 to 10 & 290 & 156 & 134 & 46.21 \\
\hline 11 to 15 & 134 & 75 & 59 & 44.03 \\
\hline 16 to 20 & 0 & 0 & 0 & 0 \\
\hline 21 to 30 & 0 & 0 & 0 & 0 \\
\hline \multicolumn{5}{|l|}{ Baiken } \\
\hline 5 to 10 & 191 & 85 & 106 & 55.5 \\
\hline 11 to 15 & 130 & 57 & 73 & 56.15 \\
\hline 16 to 20 & 0 & 0 & 0 & 0 \\
\hline 21 to 30 & 0 & 0 & 0 & 0 \\
\hline
\end{tabular}

Table 3: Prevalence of haematuria in Owena, Kajola and Baiken Communities (between March 2014 and April 2015). Source: Peletu- Field Survey of Owena Reservoi Area, Owena, Kajola and Baiken Communities (between March 2014 and April 2015).

\begin{tabular}{|c|c|c|c|c|c|c|c|c|c|c|c|c|}
\hline \multirow{2}{*}{ Variable } & \multirow{2}{*}{ Cases } & \multicolumn{2}{|c|}{ Owena $(n=242)$} & \multicolumn{2}{|c|}{ Kajola $(n=203)$} & \multicolumn{2}{|c|}{ Baiken $(n=187)$} & \multicolumn{2}{|c|}{ Total } & \multirow{2}{*}{$x^{2}$} & \multirow{2}{*}{$d f$} & \multirow{2}{*}{ P-value } \\
\hline & & No & $\%$ & No & $\%$ & No & $\%$ & No & $\%$ & & & \\
\hline \multirow{5}{*}{$\begin{array}{l}\text { Period of notice of } \\
\text { Blood in Urine }\end{array}$} & Not Applicable & 84 & 34.71 & 47 & 23.15 & 47 & 25.13 & 178 & 28.2 & \multirow{5}{*}{13.988} & \multirow{5}{*}{8} & \multirow{5}{*}{0.82} \\
\hline & 1 Month and Below & 23 & 9.5 & 27 & 13.3 & 23 & 12.3 & 73 & 11.6 & & & \\
\hline & 2 Months to 1 Year & 24 & 9.92 & 33 & 16.26 & 26 & 13.9 & 83 & 13.1 & & & \\
\hline & 2 to 5 Year & 98 & 40.5 & 91 & 44.83 & 83 & 44.38 & 272 & 43 & & & \\
\hline & 6 to 10 Year & 13 & 5.37 & 5 & 2.46 & 8 & 4.28 & 26 & 4.1 & & & \\
\hline \multirow{4}{*}{$\begin{array}{l}\text { Danger of blood in } \\
\text { urine }\end{array}$} & Very Dangerous & 21 & 8.68 & 33 & 16.26 & 76 & 40.64 & 130 & 20.6 & \multirow{4}{*}{97.04} & \multirow{4}{*}{6} & \multirow{4}{*}{0} \\
\hline & Moderate & 49 & 20.25 & 36 & 17.73 & 19 & 10.16 & 104 & 16.5 & & & \\
\hline & Not Dangerous & 118 & 48.76 & 55 & 27.09 & 45 & 24.06 & 218 & 34.5 & & & \\
\hline & Don't Know & 54 & 22.31 & 79 & 38.92 & 47 & 25.13 & 180 & 28.5 & & & \\
\hline \multirow{4}{*}{$\begin{array}{l}\text { Educational } \\
\text { background }\end{array}$} & None & 14 & 5.79 & 3 & 1.48 & 0 & 0 & 17 & 2.7 & \multirow{4}{*}{555.75} & \multirow{4}{*}{6} & \multirow{4}{*}{0} \\
\hline & Primary & 8 & 3.31 & 194 & 95.57 & 179 & 95.72 & 381 & 60.3 & & & \\
\hline & Secondary & 216 & 89.26 & 4 & 1.97 & 2 & 1.07 & 222 & 35.1 & & & \\
\hline & Tertiary & 4 & 1.65 & 2 & 0.99 & 6 & 3.21 & 12 & 1.9 & & & \\
\hline \multirow{4}{*}{ Ethnic Group } & Yoruba & 216 & 89.26 & 181 & 89.16 & 163 & 87.17 & 560 & 88.6 & \multirow{4}{*}{3.024} & \multirow{4}{*}{6} & \multirow{4}{*}{0.806} \\
\hline & Hausa & 3 & 1.24 & 4 & 1.97 & 5 & 2.67 & 12 & 1.9 & & & \\
\hline & Ibo & 22 & 9.09 & 18 & 8.87 & 19 & 10.16 & 59 & 9.3 & & & \\
\hline & Others & 1 & 0.41 & 0 & 0 & 0 & 0 & 1 & 0.2 & & & \\
\hline \multirow{2}{*}{$\begin{array}{l}\text { Snails seen around } \\
\text { reservoir/river }\end{array}$} & Yes & 214 & 88.43 & 183 & 90.15 & 164 & 87.7 & 561 & 88.8 & \multirow{2}{*}{0.629} & \multirow{2}{*}{2} & \multirow{2}{*}{0.73} \\
\hline & No & 28 & 11.57 & 20 & 9.85 & 23 & 12.3 & 71 & 11.23 & & & \\
\hline Snails responsible & Yes & 17 & 7.02 & 25 & 12.32 & 28 & 14.97 & 70 & 11.1 & 7233 & 2 & 0027 \\
\hline for blood in urine & No & 225 & 92.98 & 178 & 87.68 & 159 & 85.03 & 562 & 88.9 & 1.200 & 2 & $0.0<1$ \\
\hline & Rain & 35 & 14.46 & 29 & 14.29 & 28 & 14.97 & 92 & 14.6 & & & \\
\hline & Well & 54 & 22.31 & 53 & 26.11 & 49 & 26.2 & 156 & 24.7 & & & \\
\hline $\begin{array}{l}\text { Usual source of } \\
\text { water supply }\end{array}$ & River & 138 & 57.02 & 101 & 49.75 & 98 & 52.41 & 337 & 53.3 & 6.97 & 8 & 0.539 \\
\hline & Pond & 6 & 2.48 & 4 & 1.97 & 5 & 2.67 & 15 & 2.4 & & & \\
\hline & All & 9 & 3.72 & 16 & 7.88 & 7 & 3.74 & 32 & 5.1 & & & \\
\hline
\end{tabular}


Citation: Peletu BJ, Ofoezie IE, Olaniyan RF (2018) Transmission of Urinary Schistosomiasis among School Aged Children in Owena, Kajola and Baiken Communities Bordering Owena Reservoir/Dam, Ondo East Local Area, Ondo State, Southwest, Nigeria. Hydrol Current Res 9: 289. doi: 10.4172/2157-7587.1000289

Page 7 of 8

\begin{tabular}{|c|c|c|c|c|c|c|c|c|c|c|c|c|}
\hline \multirow{3}{*}{ Sanitary facility } & Water Cistern/Closet & 6 & 2.48 & 6 & 2.96 & 4 & 2.14 & 16 & 2.5 & \multirow{3}{*}{23.87} & \multirow{3}{*}{4} & \multirow{3}{*}{0} \\
\hline & River & 208 & 85.95 & 191 & 94.09 & 180 & 96.26 & 579 & 91.6 & & & \\
\hline & Dung Hill & 28 & 11.57 & 6 & 2.96 & 3 & 1.6 & 37 & 5.9 & & & \\
\hline \multirow{4}{*}{$\begin{array}{l}\text { Treatment for } \\
\text { schistosomiasis } \\
\text { infection }\end{array}$} & $\begin{array}{l}\text { Treatment at Local } \\
\text { Health Officers }\end{array}$ & 16 & 6.61 & 5 & 2.46 & 17 & 9.09 & 38 & 6 & \multirow{4}{*}{53.213} & \multirow{4}{*}{6} & \multirow{4}{*}{0} \\
\hline & Self-Medication & 117 & 48.35 & 133 & 65.52 & 142 & 75.94 & 392 & 62 & & & \\
\hline & Other Methods & 34 & 14.05 & 26 & 12.81 & 6 & 3.21 & 66 & 10.4 & & & \\
\hline & None & 75 & 30.99 & 39 & 19.21 & 22 & 11.76 & 136 & 21.5 & & & \\
\hline \multirow{7}{*}{ Age Group (Years) } & 5 to 10 & 5 & 2.07 & 137 & 67.49 & 119 & 63.64 & 261 & 41.3 & \multirow{7}{*}{304.69} & \multirow{7}{*}{12} & \multirow{7}{*}{0} \\
\hline & 11 to 15 & 134 & 55.37 & 61 & 30.05 & 60 & 32.09 & 255 & 40.4 & & & \\
\hline & 16 to 20 & 38 & 15.7 & 0 & 0 & 0 & 0 & 38 & 6 & & & \\
\hline & 21 to 30 & 37 & 15.29 & 1 & 0.49 & 0 & 0 & 38 & 6 & & & \\
\hline & 31 to 40 & 12 & 4.96 & 1 & 0.49 & 3 & 1.6 & 16 & 2.5 & & & \\
\hline & 41 to 50 & 12 & 4.96 & 3 & 1.48 & 4 & 2.14 & 19 & 3 & & & \\
\hline & 51 to 60 & 4 & 1.65 & 0 & 0 & 1 & 0.53 & 5 & 0.8 & & & \\
\hline
\end{tabular}

Table 4: Group and community response (\%) to questions addressing schistosomiasis transmission patterns in Owena, Kajola and Baiken communities (Owena Reservoir Area) (between March 2014 and April 2015).

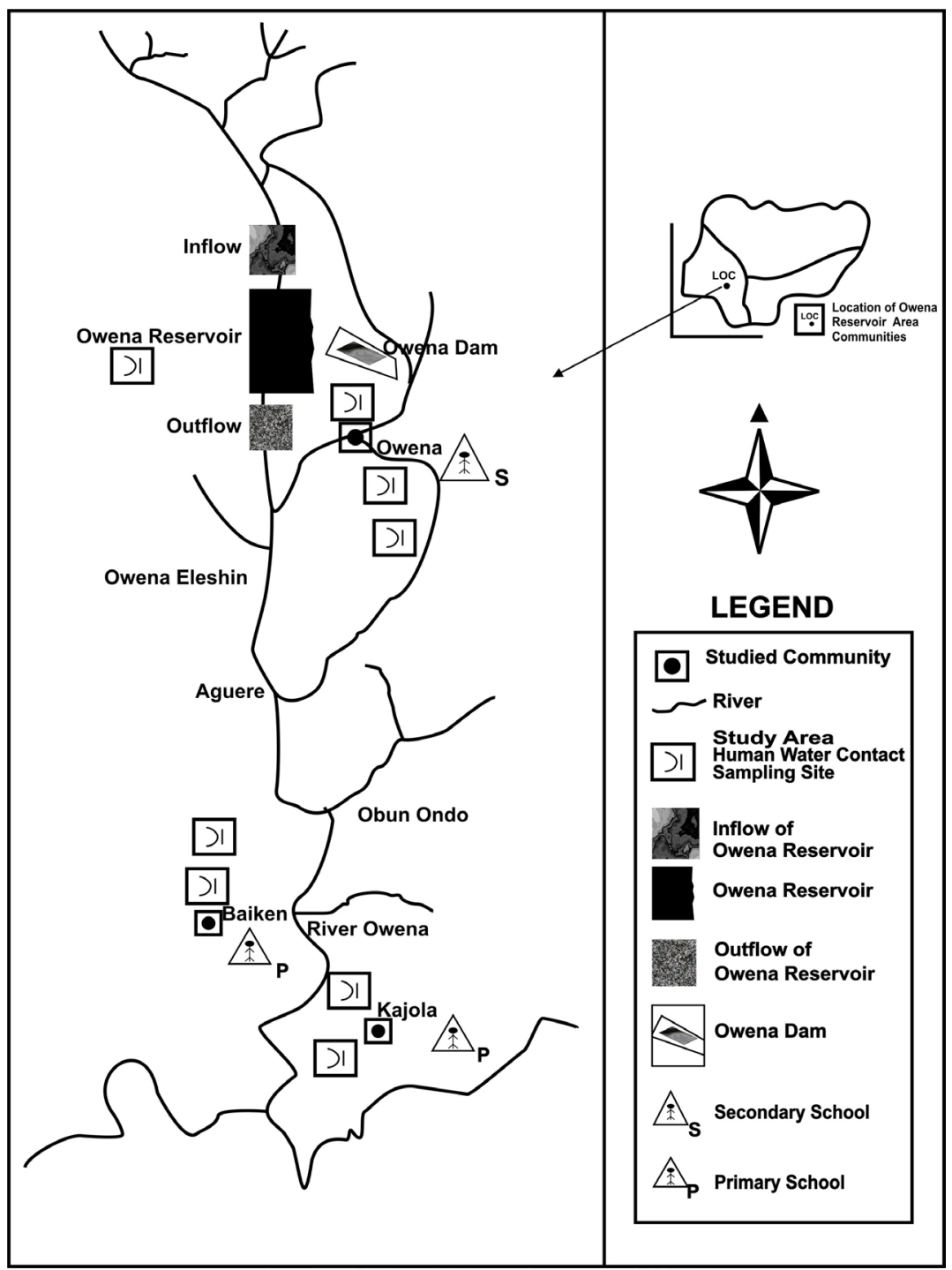

Figure 2: Map of Owena showing Owena Reservoir, Owena Dam, Owena River and the eight sampling sites of Owena, Baiken, and Kajola communities. Source: Adapted from Map of Ondo East LGA, Ondo State, Nigeria- Igboloro and Associates (Planners, Architects and Engineers), 3, Ayodele Awodeyi Street, Ketu, Lagos, Lagos State, Nigeria (2012). 
Citation: Peletu BJ, Ofoezie IE, Olaniyan RF (2018) Transmission of Urinary Schistosomiasis among School Aged Children in Owena, Kajola and Baiken Communities Bordering Owena Reservoir/Dam, Ondo East Local Area, Ondo State, Southwest, Nigeria. Hydrol Current Res 9: 289. doi: 10.4172/2157-7587.1000289

Page 8 of 8

\section{Acknowledgements}

The authors express our thanks to the communities' heads, parents, school children, Ondo State Ministry of Education, Teaching Service Commission (TESCOM) for their cooperation in the collection of all the data for this 24 months (August 2013-July 2015).

\section{References}

1. Ofoezie IE (1995) A Study of Urinary Schistosomiasis Transmission in Resettlement Communities brodering bor Oyan River Dam, Ogun State, Nigeria. PhD Thesis, 273, Obafemi Awolowo University, Ile-Ife, Nigeria.

2. Adeniyi IF, Akinbuwa O (1996) Seasonal variation, distribution and interrelationships of rotifers in Opa Reservoir, Nigeria. African Journal of Ecology 34: 351-363.

3. Peletu BJ (2010) Ecology of Fresh Water Snails Transmitting Schistosoma haematobium in Aponmu-Lona River Basin, Idanre, Ondo State, Nigeria. MSc Thesis, 107, Obafemi Awolowo University, lle-Ife, Nigeria.

4. Ahmad MM, Abubakar MM, Lawal M, Shuaibu I, Tijani AM (2015) Urinary and Intestinal schistosomiasis among primary school aged children in Dutse Jigawa State, Nigeria. International Journal of Biological Sciences (IJBS) 2 : 15-22.

5. Sowemimo OA, Asaolu SO, Babatunde TA (2013) Urinary schistosomiasis among pre-school and school aged children in two peri-urban communities in Southwest Nigeria. Journal of Parasitology and Vector Biology S17: 96-110.

6. Peletu BJ (2016) Schistosoma Intermediate Host Profile, Ecological Variations and Human Factors Influencing Schistosomiasis Transmission in Owena Reservoir Area, Ondo State, Nigeria. Ph D Thesis, 217, Obafemi Awolowo University, Ile-Ife, Nigeria.

7. Ekpo UF, Akintunde L, Oluwole AS, Sam-Wobo SO, Mafiama E (2013) Urinary schistosomiasis among pre-school children in a rural community near Abeokuta, Nigeria. Parasite and Vector 3: 58.

8. World Health Organization (2015) Updated Facts on Schistosomiasis WHOTDRS 912.

9. Jordan P, Webbe G, Sturrock FS (1993) Human schistosomiasis. Wallingford CAB International, pp: 159-193.

10. World Health Organization (2014) Urine Filtration technique for S. haematobium infection Geneva, WHO.

11. Medical Encyclopedia, Atlanta (GA) ADAM (2011) Diseases and Conditions of Schistosomiasis: Centers for Disease Control Prevention, USA.

12. Weinland W (1858) Digenea Schistosomatidae and the intermediate snail host general. Revue de Zoologie Africaine Tervuren 100: 137-152.

13. Ofoezie IE (2002) Human health and sustainable water resources development in Nigeria: Schistosimiasis in artificial lakes. Natural Resources Forum 26: 150-160.

14. Oladejo SO, Ofoezie IE (2006) Unabated schistosomiasis in Erinle river dam, Osun State Nigeria: evidence of neglect of environmental effects of developments. Journal of Tropical Medicine and International Health 11: 843850 .

15. Olorunda JO (2010) Human behavioural patterns in relation to prevalence and intensity of urinary schistosomiasis in Aponumu-Lona, Idanre, Ondo State Nigeria. MSc Thesis, Obafemi Awolowo University, Ile-Ife.

16. Ugbomoiko US, Ofoezie IE, Okoye IC, Heukelbach H (2010) Factors associated with urinary schistosomiasis in two peri-urban communities in South-western Nigeria. Annals of Tropical Medicine and Parasitology 104: 409-419.

17. World Bank (1993) World Development Report 1993: Investing in Health Oxford University Press.

18. Morenikeji OA, Idowu AB (2011) Studies on the prevalence of urinary schistosomiasis in Ogun State, Southwest Nigeria. West African Journal of Medicine 30: 62-65.
19. Odaibo AO, Olofintoye LK (2006) Unitary Schistosomiasis among school pupils in Ondo and Ekiti States, Nigeria. The Zoologist 1: 92-93.

20. Farooq M, Hairson NG (1966) The epidemiology of Schistosoma haematobium and Schistosoma mansoni infections in the Egypt-49 project area. IV. Measurement of incidence of biharziasis, Bulletin of Word Health Organization Geneva 35: 331-338.

21. Husting EL (1970) Sociological patterns and their influence on the transmission of Biharziasis. Central African Journal of Medicine.

22. Ofoezie IE, Asaolu SO, Christensen NO, Madsen H (1997) Patterns of infection this Schistosoma haematobium in lakeside resettlement communities in Oyan Reservoir in Ogun State, South-Western Nigeria. Annuals of Tropical Medical and Parasitology 91: 137-197.

23. Ogbeide $\mathrm{HE}$, Uyigue $\mathrm{E}$ (2004) Access to safe drinking water and schistosomiasis in Nigeria: survey in Ipogun Community, Ondo State of Nigeria. Submitted to the Society for Water and Public Health Protection (SWAPHEP) Reclamation, p: 104.

24. Babatunde TA, Asaolu SO, Sowemimo OA (2013) Urinary schistosomiasis among pre-school and school aged children in two peri-urban communities in Southwest Nigeria. Journal of Parasitology and Vector Biology S17: 96-110.

25. Ibironke O, Philips A, Garba A, Lamine S, Shift C (2015) Diagnosis of Schistosoma haematobium by defection of specific DNA Fragments from filtered Urine Sample. Am J Trop Med Hyg 84: 998-1001.

26. Oladejo SO (2011) Assessment Schistosomiasis using Geographic Information System/Remote Sensing in Osun State, South West, Nigeria. Conversion from $\mathrm{M} / \mathrm{Phil} / \mathrm{PhD}$ to $\mathrm{PhD}$ in Zoology, Thesis Ecology and Environmental Biology Unit University Ibadan, Nigeria.

27. Asaolu SO, Ofoezie IE (1990) A simple method for concentrating eggs of Schistosoma haematobium in the urine. The Nigerian Journal of Parasitology 9: 47-50.

28. Ishaleku D, Yako AB, Usman D, Azamu SA (2012) Schistosoma haematobium Infection among school children in Keffi Town Nassarawa State, Nigeria. Scholarly J Med 2: 104-107.

29. Amaechi EC (2014) Urinary Schistosomiasis among school age children in some rural communities of Abia State, Southeast, Nigeria. Animal Research International 11: 1953-1957.

30. Otuneme OG, Akinkuade F, Obebe OO, Usiobeigbe O, Faloye T, et al. (2014) A study on the prevalence of schistosome haematobium in a rural community of Ogun State, Nigeria, South East Asia. Journal of Public Health 5: 67-71.

31. Banji BB, Mann A, Nma EM, Obi PV, Ezeako IA (2011) Prevalence of schistosomiasis and other intestinal Helminth parasite among school children in Bida, Niger State, Nigeria. European Journal of Scientific Research, pp: 621 626.

32. Ugbomoiko SO (2000) The prevalence, incidence and distribution of human urinary schistosomiasis in Edo state, Nigeria. Nigerian Journal of Parasitology 21: 314

33. World Health Organization (2004) Schistosomiasis Division of Control of Tropical Diseases, pp: 5-7.

34. Akinwale OP, Ajayi MB, Gyangg PB, Adeleke MA, Adeneye AK, et al. (2010) Urinary schistosomiasis around Oyan Reservoir Nigeria, Twenty years after the $1^{\text {st }}$ outbreak. Iraninan Journal Public Health 39: 92-95.

35. Zar (1984) Biostatistical analysis. 2nd edn. New Jersey Prentice-Hall International, p: 718.

36. Hosmer DW, Lemeshow S (1989) Applied logistic research. New York, Toronto Singapore, p: 307.

37. Madsen $H$ (1986) The effect of sodium chloride concentration on growth and eggs laying of Helisoma duryi, Biomphalaria alexendrina and Bulinustruncatus (Gastropoda: Planorbidae). Journal of Molluscan Studies 56: 181-187. 